\title{
Contribution of illegal hunting, culling of pest species, road accidents and feral dogs to biodiversity loss in established oil-palm landscapes
}

\begin{abstract}
Context: Understanding the ecological impacts of the palm-oil industry on native fauna requires information on anthropogenic threats that may cause species decline or local extinction. Aim: The main aim of the study was to assess wildlife deaths caused by illegal hunting, road accidents and introduced predators in established oil-palm landscapes in Peninsular Malaysia. Methods: Between April and October 2009, we interviewed 362 oilpalm workers at 36 sites, including large industrial estates and semi-traditional smallholdings. Key results: Our results showed that (1) illegal hunting by oil-palm workers in different oilpalm management systems was not statistically significant $(\mathrm{P}=0.097),(2)$ native fauna were more often destroyed as pests in smallholdings than in conventional and eco-friendly plantation estates ( $\mathrm{P}=0.005)$, (3) non-local poachers conducted illegal activity more often in smallholdings than in conventional and eco-friendly plantation estates $(\mathrm{P}=0.011)$, (4) road accidents were reported to kill more native fauna in conventional plantation estates than in smallholdings and eco-friendly plantation estates $(\mathrm{P}<0.001)$ and $(5)$ feral dogs were reported as killing more native fauna in eco-friendly plantation estates than in conventional plantation estates and smallholdings $(\mathrm{P}=0.034)$. Conclusion: In addition to the conversion of native forest to oil-palm monocultures, various other anthropogenic threats can have a substantial effect on wildlife in oil-palm landscapes. Implications: To improve the conservation value of oil-palm landscapes, we recommend that palm-oil stakeholders should implement antipoaching patrols, organise conservation programs to educate workers, reduce vehicle speeds on roads within oil-palm landscapes, and control local populations of feral dogs.
\end{abstract}

Keyword: Anthropogenic threats; Conventional plantation estates; Eco-friendly plantation estates; Semi-traditional smallholdings 